\title{
Analysis of Service Quality using Servqual Method and Importance Performance Analysis (IPA) in Population Department, Tomohon City
}

\author{
Marlin Yuvina Tileng \\ Faculty of Information Technology \\ Satya Wacana Christian University \\ Diponegoro Street, 52-60 Salatiga \\ 50711, Indonesia
}

\author{
Wiranto Herry Utomo \\ Faculty of Information Technology \\ Satya Wacana Christian University \\ Diponegoro Street, 52-60 Salatiga \\ 50711, Indonesia
}

\author{
Rudy Latuperissa \\ Faculty of Information Technology \\ Satya Wacana Christian University \\ Diponegoro Street, 52-60 Salatiga \\ 50711, Indonesia
}

\begin{abstract}
The purpose of this study was to determine the indicators of quality of service that be priority to enhanced by Department of Population, Tomohon in serving the public. In research using Importance Performance Analysis (IPA) to analyze. Type of data used are primary data by giving the questionnaires to the society to obtain or collect data on perceptions and expectations of the society. Perceptions and expectations of the society based on the five dimensions quality of service that is : tangible, reliability, responsiveness, assurance, and empathy. The fifth dimension of this be created some questions tailored to the Likert scale, where questions are asked about the satisfaction of performance were given a choice answers from very satisfied until not satisfied, and the question of the interests were given the answers of customers is very important until not important. Each questions from every dimension the existing, tested by using a validity test using SPSS software and reliability using Cronbach Alpha.
\end{abstract}

\section{Keywords}

Importance Performance Analysis (IPA), Quality of Service.

\section{INTRODUCTION}

Parasuraman Zeithaml and Berry (1991) stated that service quality is the comparison between service expected consumers with the services received. In other words if the services received or perceived consistent with those expected by the user, then quality of service perceived is good and satisfying. If the service or services received exceed the expectations of the user, then perceived to quality of service as ideal quality. But otherwise if the services received is lower than expected, then quality of service perceived a bad. Quality of service must be started of the needs of users and ends on responses user. User responses on the quality of the service itself constitute a thorough assessment against superiority of a service [2].

Department of Population Tomohon one agencies that is engaged in service to society in handling civil documents, such as ID card, Birth Certificate, Death Certificate, Divorce Certificate and Marriage Certificate. The frequent gets complaints of public regarding the performance or quality of service of Department of Population, then need to be evaluated to be able find out the extent to which the quality of services provided.

Use of Importance Performance Analysis (IPA) to analyze as Cartesians diagram, and consists of four quadrants. The data used are primary data which distributed to the society to elicit a response about the perceptions and expectations of public regarding the quality of service of the Department of Population Tomohon. Perceptions and expectations of public based on the five dimensions of service quality that is: tangible, reliability, responsiveness, assurance and empathy.

The benefits of this research conducted in order into consideration to the service of Department of Population Tomohon to do development of or improvement of services provided mainly concerned with the satisfaction of society and also as an evaluation.

\section{LITERATURE REVIEW}

\subsection{Research Preview}

a. Research conducted by Budi Puspitasari Nia, et al, about Analisis Kualitas Pelayanan dengan menggunakan integrasi Importance Performance Analysis (IPA) dan Model Kano pada PT. Perusahaan Air Minum Lyonnaise Jaya Jakarta. This research was conducted by integrating Importance Performance Analysis (IPA) and the Kano Model. Importance Performance Analysis (IPA) is used to find out what attributes are included in quadrant I, II, III, and IV on the Importance Performance Matrix. Having acquired the attributes of each quadrant, the next is to integrate the attribute classification by category canoe with identification quadrants on Importance Performance Matrix. Importance Performance Analysis Based on the integration of the Kano Model to note that the attributes that need to enhanced is the application of priority facilities Palyja water can be drunk directly by consumers [1].

b. Research of Desy Herawati about Perencanaan Peningkatan Kualitas Pelayanan Perijinan pada Pemerintah Kota Padang. This research is to compare the conditions of licensing services with minimum service standards, analyze the level of people's satisfaction licensing services, comparing people's expectations and appraisal licensing services and service improvement planning permission. The analysis showed that the licensing service conditions do not meet the standard of care, Community Satisfaction Index for licensing services, namely 3.365 (conversion value of 67.3) belong to the category C. Importance Performance Analysis of the matrix shows the highest priority quality improvement aspects of licensing should be done at the speed of service and timeliness of completion of the document. Planning is formulated based on the results of previous analysis 
consists from two policies, and four programs, as well as eight activities for the improvement of service quality permit [3].

c. The research entitled A Comparison of SERVQUAL and IP Analysis: Measuring and Improving Service Quality in Egyptian Private Universities by Mohamed M. Mostafa. This research was conducted to determine the quality of service of private universities in Egypt. Through Importance Performance Analysis, 22 attributes of quality of service is divided into four quadrants. The result shows that 9 attributes lies in quadrant I (concentrate here), 2 attributes in quadrant II (keep up the good work), 8 attributes in quadrant III (lower priority), and 3 attributes in quadrant IV (possible overkill) [11].

\subsection{Importance Performance Analysis (IPA)}

Importance Performance Analysis is a series of service attributes associated with specific services to be evaluated based on the level of importance according to the consumer of each attribute and how the service is perceived its performance relative to each attribute. Analysis was used to compare between consumer ratings of the importance of quality of service (Importance) with the level of service quality performance (Performance). Average of results overall assessment of consumer then be described in Importance Performance Matrix or often called the Cartesian diagram. Average of level of performance is used as a delimiter of high performance and low performance. Average of interests rate is used as a delimiter high level of importance with a low interests of rate. Importance Performance Matrix is divided into four quadrants based on importance-performance measurement result as shown in the figure below: (see Figure 1).

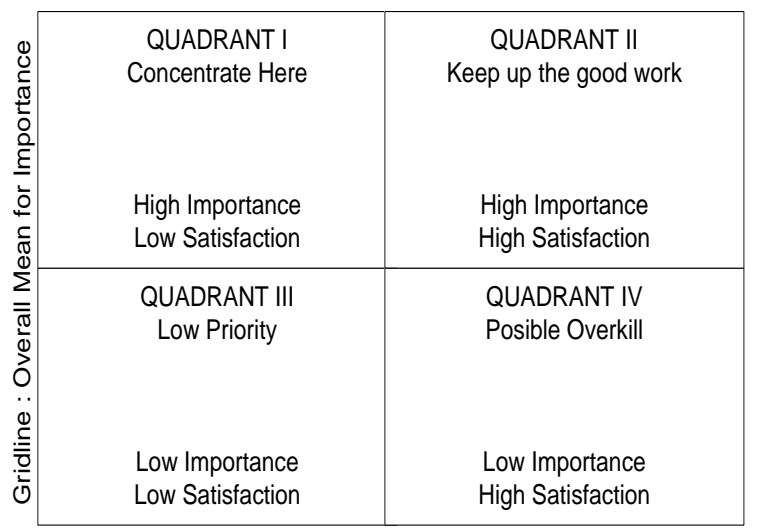

Fig 1: Importance Performance Analysis Chart

1. The following an explanation for each quadrant is: Quadrant one, "Concentrate Here" (high importance and low satisfaction).

The factors included in this quadrant is factors that are considered important by customers. But the reality of these factors does not meet customer expectations (level of satisfaction obtained is low). The variables included in this quadrant should be improved.

2. Quadrant two, "Keep up the Good Work" (high importance and high satisfaction).

This quadrant includes the factors who are considered important by customers, and considered to be accordance with that is felt so that relatively higher level of satisfaction.
3. Quadrant three, "Low Priority" (low importance and low satisfaction).

The factors included in this quadrant is considered less importance. Increased the variables included in this quadrant can reconsidered because of its influence on the benefits perceived by customers very smaller.

4. Quadrants four, "Possible Overkill" (low importance and high satisfaction).

The factors this quadrant is considered less important by customers. The variables included in this quadrant can be reduced so that the company can save costs. [4]

Importance Performance Analysis developed by Martilla and James (1977) as a tool for analyzing customer satisfaction based on the attributes of service quality. [10]

\subsection{Quality of Service}

Quality of service is the rate of excellence expected and control over the level of excellence to meet customer desires [5].

Dimensions of service quality in the Servqual based on the multi-items scales that are designed to measure customer expectations and perceptions as well as the gap between them in the service quality dimensions. Was originally Parasuraman et al (1985) identified ten the principal dimensions with 22 variables related to the servicing and then analyzed using factor analysis. Such criteria include 10 potential that complements one another dimensions include tangibles, reliability, responsiveness, communication, credibility, security, competence, courtesy, understanding, and access. Parasuraman 1988 later simplifying to 5 dimensions, that is: [6]

1. Tangibles covers the physical facilities, equipment, personnel and communication facilities.

2. Reliability covers capabilities provide the promised services with immediately, an accurate, and satisfactorily.

3. Responsiveness that is the wish of the staff to help customers and provide service with responsiveness.

4. Assurance covers the knowledge, capabilities, courtesy, and trustworthiness are owned by the staff, free of the dangers, risk, or doubt.

5. Empathy that is: ease of doing relationships, good communication, personalized attention, and understanding of customer needs

\section{METHODS AND ANALYSIS}

\subsection{Identification of Research Variables}

Based on the background that have been proposed then the variables to be studied are the perceptions and expectations of society. The research variables were used to assess the services of the Department of Population Tomohon by using the attributes of tangibles dimension, reliability, responsiveness, assurance, and empathy. Perceptions and expectations of society of the quality service Department of Population Tomohon using score 1-5. Each score was given the following description:

- Score 5 represents very satisfied answer.

- Score 4 representing satisfied answer.

- Score 3 representing answer is quite satisfied.

- Score 2 representing less satisfied answer.

- Score 1 representing answer is not satisfied. 


\subsection{Collection of Data}

Data acquired for this research from primary data. Primary data are taken from the object research by using a questionnaire propagated to society. The questionnaire consists of 20 the questions.

\subsection{Sampling}

Population of this study is infinite (unlimited), because number of customers to vary over time. Sample used considered to have represented of all population. Samples randomly selected (simple random sampling), because it is considered suitably representative (representatives). Samples of data used In this research, 92 samples were gained from 100 respondents who meet the requirements of many as 92 respondents.

\subsection{Reliability Test}

Reliability actually a tool to measure a questionnaire which is an indicator of the variables or constructs. Questioner said to be reliable or reliable if answer a person to questions are consistent or stabilized over time [7]. In conducting the reliability test using SPSS version 13.0 for Windows. According Nunnally (1960), a construct or variables said to be reliable if it is providing value Crobanch Alpha>0.60.

Based on reliability test results between the perception of and expectations of customers from questionnaire distributed, the value Crobanch Alpha> 0.60, where the perceptions value Crobanch Alpha 0.975, whereas expectation, value of Crobanch Alpha 0.941 (see Table 1 and Table 2). This result means that the questionnaire used in this research is expressed reliable.

Table 1. Alpha Crobanch Value Perception Reliability Statistics

\begin{tabular}{|r|r|}
\hline $\begin{array}{c}\text { Cronbach's } \\
\text { Alpha }\end{array}$ & N of Items \\
\hline, 975 & 20 \\
\hline
\end{tabular}

Table 2. Alpha Crobanch Value Expectations Reliability Statistics

\begin{tabular}{|r|r|}
\hline $\begin{array}{c}\text { Cronbach's } \\
\text { Alpha }\end{array}$ & N of Items \\
\hline, 941 & 20 \\
\hline
\end{tabular}

\subsection{Validity Test}

Validity test of data are used to measure legitimate not an or valid questionnaire. Valid mean the instruments used can be measure what was be measured. Validity of a measure is used describing the suitability of data with what was to be measured. In testing the validity of using SPSS version 13.0 for Windows. Decision making based on significance value less than $0.05(5 \%)$, then the item of question was stated valid . Significance value obtained based on the $\mathrm{df}=\mathrm{n}-2$, where the $\mathrm{df}$ is the degrees of freedom and $\mathrm{n}$ is the number of data. If the count value of $r$ (Corrected item total correlation) is greater than the table $r$ and is positive, then the of the questions or the indicator is valid (see Table 3) [8].
Table 1. Table Value Correlation Coefficient " $r$ " Product Moment

(Source: Sugiyono, 1999)

\begin{tabular}{|c|c|c|c|c|c|c|c|c|}
\hline \multirow{2}{*}{$\mathbf{N}$} & \multicolumn{2}{|c|}{ Taraf Signif } & \multirow{2}{*}{$\mathbf{N}$} & \multicolumn{2}{c|}{ Taraf Signif } & \multirow{2}{*}{$\mathbf{N}$} & \multicolumn{2}{c|}{ Taraf Signif } \\
& $\mathbf{5 \%}$ & $\mathbf{1 \%}$ & & $\mathbf{5 \%}$ & $\mathbf{1 \%}$ & & $\mathbf{5 \%}$ & $\mathbf{1 \%}$ \\
\hline 3 & 0,997 & 0,999 & 27 & 0,381 & 0,487 & 55 & 0,266 & 0,345 \\
\hline 4 & 0,950 & 0,990 & 28 & 0,374 & 0,478 & 60 & 0,254 & 0,330 \\
\hline 5 & 0,878 & 0,959 & 29 & 0,367 & 0,470 & 65 & 0,244 & 0,317 \\
\hline 6 & 0,811 & 0,917 & 30 & 0,361 & 0,463 & 70 & 0,235 & 0,306 \\
\hline 7 & 0,754 & 0,874 & 31 & 0,355 & 0,456 & 75 & 0,227 & 0,296 \\
\hline 8 & 0,707 & 0,834 & 32 & 0,349 & 0,349 & 80 & 0,220 & 0,286 \\
\hline 9 & 0,688 & 0,798 & 33 & 0,344 & 0,442 & 85 & 0,213 & 0,278 \\
\hline 10 & 0,632 & 0,765 & 34 & 0,339 & 0,436 & 90 & 0,207 & 0,270 \\
\hline 11 & 0,602 & 0,735 & 35 & 0,334 & 0,430 & 95 & 0,202 & 0,263 \\
\hline 12 & 0,576 & 0,708 & 36 & 0,329 & 0,424 & 100 & 0,195 & 0,256 \\
\hline 13 & 0,553 & 0,684 & 37 & 0,325 & 0,418 & 125 & 0,176 & 0,230 \\
\hline 14 & 0,532 & 0,661 & 38 & 0,320 & 0,413 & 150 & 0,159 & 0,210 \\
\hline 15 & 0,514 & 0,641 & 39 & 0,316 & 0,408 & 175 & 0,148 & 0,194 \\
\hline 16 & 0,497 & 0,623 & 40 & 0,312 & 0,403 & 200 & 0,136 & 0,181 \\
\hline 17 & 0,482 & 0,606 & 41 & 0,308 & 0,398 & 300 & 0,113 & 0,148 \\
\hline 18 & 0,468 & 0,590 & 42 & 0,304 & 0,393 & 400 & 0,098 & 0,128 \\
\hline 19 & 0,456 & 0,575 & 43 & 0,301 & 0,389 & 500 & 0,088 & 0,115 \\
\hline 20 & 0,444 & 0,581 & 44 & 0,297 & 0,384 & 600 & 0,080 & 0,105 \\
\hline 21 & 0,433 & 0,549 & 45 & 0,294 & 0,380 & 700 & 0,074 & 0,097 \\
\hline 22 & 0,423 & 0,537 & 46 & 0,291 & 0,378 & 800 & 0,070 & 0,091 \\
\hline 23 & 0,413 & 0,526 & 47 & 0,288 & 0,372 & 900 & 0,065 & 0,086 \\
\hline 24 & 0,404 & 0,515 & 48 & 0,284 & 0,368 & 1000 & 0,062 & 0,081 \\
\hline 25 & 0,396 & 0,505 & 49 & 0,281 & 0,364 & & & \\
\hline
\end{tabular}

In this research the number of data used 92 data. For degrees of freedom (df) is $\mathrm{df}=\mathrm{n}-2$, that is: $92-2$. So, $\mathrm{df}=90$. On the tables the value of the correlation coefficient " $r$ " product moment $\mathrm{df}=90$ with a level of significance $5 \%$ worth 0.207 (see Table 3).

Based on results of the data processing of society perceptions by using the SPSS is obtained that the value of $r$ count (column Corrected item total correlation) to each of the questions greater than $r$ table worth 0.207 . So that each item of question is expressed valid (see Table 4). 
Table 4. Result Data Processing Perception

(Source: Data processed by SPSS)

Item-Total Statistics

\begin{tabular}{|l|r|r|r|r|}
\hline & $\begin{array}{c}\text { Scale Mean if Item } \\
\text { Deleted }\end{array}$ & $\begin{array}{c}\text { Scale Variance if } \\
\text { Item Deleted }\end{array}$ & $\begin{array}{c}\text { Corrected Item- } \\
\text { Total Correlation }\end{array}$ & $\begin{array}{c}\text { Cronbach's Alpha if } \\
\text { Item Deleted }\end{array}$ \\
\hline VAR00001 & 68,8427 & 323,839 &, 828 &, 974 \\
\hline VAR00002 & 68,9888 & 327,102 &, 785 &, 974 \\
\hline VAR00003 & 69,1124 & 327,737 &, 794 &, 974 \\
\hline VAR00004 & 69,1910 & 329,088 &, 750 &, 974 \\
\hline VAR00005 & 69,0337 & 326,874 &, 800 &, 974 \\
\hline VAR00006 & 69,1798 & 327,945 &, 979 &, 974 \\
\hline VAR00007 & 69,0000 & 325,909 &, 874 \\
\hline VAR00008 & 69,1573 & 327,520 &, 821 &, 974 \\
\hline VAR00009 & 68,9213 & 324,914 &, 799 &, 974 \\
\hline VAR00010 & 69,1124 & 328,101 &, 784 &, 974 \\
\hline VAR00011 & 69,0899 & 328,174 &, 802 &, 974 \\
\hline VAR00012 & 69,1348 & 328,550 &, 838 &, 974 \\
\hline VAR00013 & 69,1348 & 327,823 &, 799 &, 974 \\
\hline VAR00014 & 68,9775 & 326,318 &, 812 &, 974 \\
\hline VAR00015 & 69,0899 & 326,765 &, 831 &, 974 \\
\hline VAR00016 & 69,1124 & 326,874 &, 841 &, 974 \\
\hline VAR00017 & 68,9663 & 326,828 &, 747 &, 975 \\
\hline VAR00018 & 69,2022 & 328,686 &, 974 \\
\hline VAR00019 & 68,8539 & 325,422 &, 974 \\
\hline VAR00020 & 69,1348 & 327,913 &, 974 \\
\hline
\end{tabular}

Based on results of the data processing of society expectations by using the SPSS are obtained that the value of $r$ count questions, greater than $r$ table that is worth 0.207 so that every item of question expressed valid (see Table 5).

(column Corrected item total correlation) to each of the

Table 5. Result Data Processing Expectations (Source: Data processed by SPSS)

Item-Total Statistics

\begin{tabular}{|c|c|c|c|c|}
\hline & $\begin{array}{c}\text { Scale Mean if Item } \\
\text { Deleted }\end{array}$ & $\begin{array}{l}\text { Scale Variance if } \\
\text { Item Deleted }\end{array}$ & $\begin{array}{l}\text { Corrected Item- } \\
\text { Total Correlation }\end{array}$ & $\begin{array}{l}\text { Cronbach's Alpha if } \\
\text { Item Deleted }\end{array}$ \\
\hline VAR00001 & 66,3258 & 196,745 & ,721 & ,937 \\
\hline VAR00002 & 66,0000 & 196,205 & ,580 & ,940 \\
\hline VAR00003 & 66,0674 & 195,700 & ,711 & ,937 \\
\hline VAR00004 & 66,0449 & 194,907 & ,613 & ,939 \\
\hline VAR00005 & 66,2360 & 196,341 & ,634 & ,939 \\
\hline VAR00006 & 66,3034 & 197,191 & ,590 & ,939 \\
\hline VAR00007 & 66,0225 & 194,431 & ,719 & ,937 \\
\hline VAR00008 & 66,2135 & 196,011 & 675 & ,938 \\
\hline VAR00009 & 66,2921 & 197,618 & ,563 & ,940 \\
\hline VAR00010 & 66,1461 & 195,149 & ,659 & ,938 \\
\hline VAR00011 & 66,3258 & 197,631 & ,604 & ,939 \\
\hline VAR00012 & 66,0562 & 196,008 & ,675 & ,938 \\
\hline VAR00013 & 66,2697 & 196,586 & ,674 & ,938 \\
\hline VAR00014 & 66,0562 & 196,054 & ,637 & ,939 \\
\hline VAR00015 & 66,2135 & 195,738 & ,676 & ,938 \\
\hline VAR00016 & 66,2472 & 196,143 & ,706 & ,938 \\
\hline
\end{tabular}




\begin{tabular}{|l|r|r|r|r|}
\hline VAR00017 & 65,9101 & 194,787 &, 738 &, 937 \\
\hline VAR00018 & 66,5281 & 197,888 &, 563 &, 940 \\
\hline VAR00019 & 65,8876 & 195,374 &, 606 &, 939 \\
\hline VAR00020 & 66,0225 & 194,727 &, 657 &, 938 \\
\hline
\end{tabular}

\subsection{Analysis of the Importance \\ Performance Analysis (IPA)}

Importance Performance Analysis are used to map relationship between interests of with performance of respective attribute is offered, and gap between of performance with expectations of an attributes. Importance Performance Analysis consist of two components: quadrant analysis and gap analysis. With a quadrant analysis can be known consumer response to attributes that were plotted based on order of importance (perceptions) and performance of (expectations) of the attribute. While the gap analyses are used to see the gap between the interests an attribute with consumer expectations for these attributes (see Table 6) [9].

Table 6: SERVQUAL Dimensions

\begin{tabular}{|c|c|c|}
\hline \\
\hline No & Dimensions & Attribute \\
\hline \multirow{4}{*}{1.} & \multirow{4}{*}{ Reliability } & $\begin{array}{l}\text { 1. The service provided of employees has } \\
\text { been good while serving society }\end{array}$ \\
\hline & & $\begin{array}{ll}\text { 2. } & \begin{array}{l}\text { Employees give timely service to } \\
\text { society }\end{array} \\
\end{array}$ \\
\hline & & $\begin{array}{l}\text { 3. Absence of a mistakes made employee } \\
\text { in the process processing of documents }\end{array}$ \\
\hline & & $\begin{array}{l}\text { If there is community grievance, } \\
\text { employee immediately responded }\end{array}$ \\
\hline \multirow{4}{*}{2.} & \multirow{4}{*}{ Responsiveness } & 5. Employees serve society with fast \\
\hline & & $\begin{array}{ll}6 . & \begin{array}{l}\text { Employees give of accurate } \\
\text { information about processing of } \\
\text { documents }\end{array} \\
\end{array}$ \\
\hline & & $\begin{array}{ll}\text { 7. Employees are always ready to serve } \\
\text { the public }\end{array}$ \\
\hline & & Employees are easily contacted \\
\hline \multirow{3}{*}{3.} & \multirow{3}{*}{ Assurance } & $\begin{array}{ll}\text { 9. } & \begin{array}{l}\text { Employee have a good capabilities in } \\
\text { dealing complaints from society }\end{array} \\
\end{array}$ \\
\hline & & $\begin{array}{l}\text { 10. Employees have a good knowledge } \\
\text { about processing of documents }\end{array}$ \\
\hline & & $\begin{array}{ll}11 . & \begin{array}{l}\text { Employees ensures of data society } \\
\text { secure }\end{array} \\
\end{array}$ \\
\hline \multirow{4}{*}{4.} & \multirow{4}{*}{ Empathy } & $\begin{array}{l}\text { 12. Employees understand the needs of } \\
\text { the public as service users }\end{array}$ \\
\hline & & $\begin{array}{l}\text { 13. Employees have a sooth in responding } \\
\text { to community requests as an user the } \\
\text { service }\end{array}$ \\
\hline & & 14. Employees be friendly and courteous \\
\hline & & $\begin{array}{l}\text { 15. Employees give the same service, } \\
\text { regardless of social status }\end{array}$ \\
\hline \multirow{5}{*}{5.} & \multirow{5}{*}{ Tangible } & $\begin{array}{l}\text { 16. The condition of environment the } \\
\text { office building of a clean }\end{array}$ \\
\hline & & $\begin{array}{l}\text { 17. Attributes employee uniforms worn } \\
\text { complete and neat }\end{array}$ \\
\hline & & $\begin{array}{ll}\text { 18. } & \text { Comfort of the waiting room } \\
\text { provided }\end{array}$ \\
\hline & & 19. Adequate parking areas \\
\hline & & $\begin{array}{l}\text { 20. Equipment in the room already } \\
\text { complete }\end{array}$ \\
\hline
\end{tabular}

1. Calculating the value of perceptions and expectations of customer :

$$
\begin{aligned}
& \bar{x}=\frac{\sum x i}{n} \\
& \bar{y}=\frac{\sum y i}{n}
\end{aligned}
$$

$\bar{x}:$ average value of customer expectations

$\bar{y}:$ average value of customer perceptions

$n$ : number of sample

2. Cartesian diagram describing the level of expectation values as $X$ axis (horizontal) and the perceived level of customer value as the $\mathrm{Y}$ axis (vertical). Division of quadrant in the Cartesian diagram can be done by setting the starting point $(\mathrm{X}, \mathrm{Y})$ which traversed two intersecting upright lines. The equation is:

$$
\begin{aligned}
& \overline{\bar{x}}=\frac{\sum \overline{\bar{x}} i}{n} \\
& \overline{\bar{y}}=\frac{\sum \overline{\bar{y}} i}{n}
\end{aligned}
$$

$\overline{\bar{x}}:$ average value of expectation of all statements $\overline{\bar{y}}$ : average value of perception of all statements $n$ : number of sample 
Table 6: Average of Perceptions and Expectations of Service Quality

\begin{tabular}{|c|c|c|c|c|}
\hline \multirow[b]{2}{*}{ No } & \multirow[b]{2}{*}{ Dimensions } & \multirow[b]{2}{*}{ Attribute } & \multicolumn{2}{|c|}{ Average } \\
\hline & & & $\begin{array}{l}\text { Perception } \\
(\mathbf{X})\end{array}$ & $\begin{array}{c}\text { Expectations } \\
(\mathbf{Y})\end{array}$ \\
\hline \multirow{4}{*}{1.} & \multirow{4}{*}{ Reliability } & $\begin{array}{l}\text { 1. The service provided of } \\
\text { employees has been good } \\
\text { while serving society }\end{array}$ & 3,83 & 3,31 \\
\hline & & $\begin{array}{l}\text { 2. Employees give timely service } \\
\text { to society }\end{array}$ & 3,73 & 3,64 \\
\hline & & $\begin{array}{l}\text { 3. Absence of a mistakes made } \\
\text { employee in the process } \\
\text { processing of documents }\end{array}$ & 3,54 & 3,57 \\
\hline & & $\begin{array}{l}\text { 4. If there is community } \\
\text { grievance, employee } \\
\text { immediately responded }\end{array}$ & 3,54 & 3,60 \\
\hline \multirow{4}{*}{2.} & \multirow{4}{*}{ Responsiveness } & $\begin{array}{l}\text { 5. Employees serve society with } \\
\text { fast }\end{array}$ & 3,68 & 3,40 \\
\hline & & $\begin{array}{l}\text { 6. Employees give of accurate } \\
\text { information about processing } \\
\text { of documents }\end{array}$ & 3,49 & 3,34 \\
\hline & & $\begin{array}{l}\text { 7. Employees are always ready } \\
\text { to serve the public }\end{array}$ & 3,70 & 3,62 \\
\hline & & $\begin{array}{ll}\text { 8. } & \begin{array}{l}\text { Employees are easily } \\
\text { contacted }\end{array}\end{array}$ & 3,55 & 3,43 \\
\hline \multirow{3}{*}{3.} & \multirow{3}{*}{ Assurance } & $\begin{array}{l}\text { 9. Employee have a good } \\
\text { capabilities in dealing } \\
\text { complaints from society }\end{array}$ & 3,79 & 3,35 \\
\hline & & $\begin{array}{l}\text { 10. Employees have a good } \\
\text { knowledge about processing } \\
\text { of documents }\end{array}$ & 3,57 & 3,49 \\
\hline & & $\begin{array}{l}\text { 11. Employees ensures of data } \\
\text { society secure }\end{array}$ & 3,63 & 3,31 \\
\hline \multirow{4}{*}{4.} & \multirow{4}{*}{ Empathy } & $\begin{array}{l}\text { 12. Employees understand the } \\
\text { needs of the public as service } \\
\text { users }\end{array}$ & 3,54 & 3,58 \\
\hline & & $\begin{array}{l}\text { 13. Employees have a sooth in } \\
\text { responding to community } \\
\text { requests as an user the } \\
\text { service }\end{array}$ & 3,54 & 3,37 \\
\hline & & $\begin{array}{l}\text { 14. Employees be friendly and } \\
\text { courteous }\end{array}$ & 3,71 & 3,58 \\
\hline & & $\begin{array}{l}\text { 15. Employees give the same } \\
\text { service, regardless of social } \\
\text { status }\end{array}$ & 3,61 & 3,43 \\
\hline \multirow{5}{*}{5.} & \multirow{5}{*}{ Tangible } & $\begin{array}{l}\text { 16. The condition of environment } \\
\text { the office building of a clean }\end{array}$ & 3,57 & 3,39 \\
\hline & & $\begin{array}{l}\text { 17. Attributes employee uniforms } \\
\text { worn complete and neat }\end{array}$ & 3,76 & 3,73 \\
\hline & & $\begin{array}{l}\text { 18. Comfort of the waiting room } \\
\text { provided }\end{array}$ & 3,50 & 3,11 \\
\hline & & 19. Adequate parking areas & 3,84 & 3,75 \\
\hline & & $\begin{array}{l}\text { 20. Equipment in the room } \\
\text { already complete }\end{array}$ & 3,59 & 3,62 \\
\hline \multirow{2}{*}{\multicolumn{3}{|c|}{$\begin{array}{c}\text { Jumlah } \\
\text { Rata-rata }\end{array}$}} & 72,71 & 69,64 \\
\hline & & & 3,64 & 3,48 \\
\hline
\end{tabular}

Based on the table above shows that public perceptions of the service quality the Department of Population Tomohon an average larger than expectations. Difference is not very much (the average perception scores compared with the expectations of $3.64>3: 48$ ).
Statement of which there is will be outlined and is divided into four sections to the Cartesian diagram as follow (see Figure 2): 


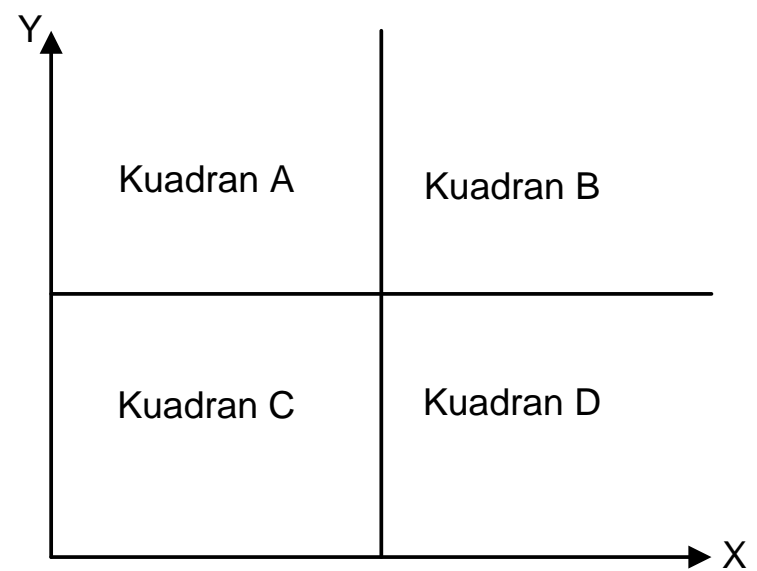

Fig 2: Cartesian Diagram

\section{Quadrant A}

The performance of a variable is lower than desires of the customer so that the company should increase its performance so that optimal.
Performance and desires of customer are at high levels and appropriate, so the company sufficient to maintain performance variables.

\section{Quadrant C}

Performance and desires of customer in a variable is at a lowlevel, so companies has not needed to make improvements.

\section{Quadrant D}

Performance of company is in a high level of performance but the desire of the customer will be the only variable is low, so companies need to reduce the results achieved to minimize the resources of the company

\section{Quadrant B}

Importance Performance Analysis

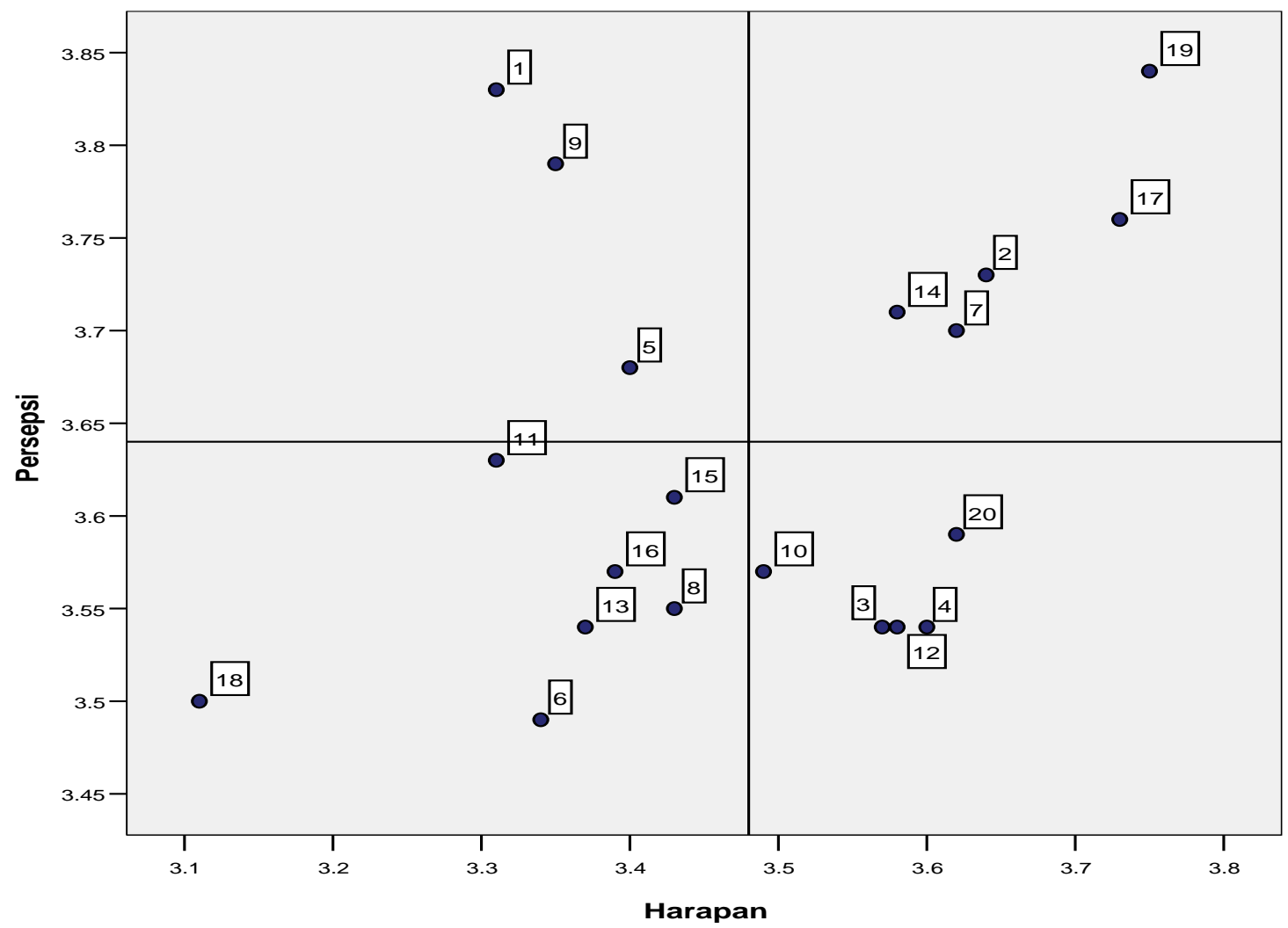

Fig 3: Importance Performance Analysis 
Based on the results of a diagram could be viewed Importance Performance Analysis attributes which included in quadrant A, B, C, D.

Attributes which included in quadrant A, is the service provided of employees has been good while serving society (1), employees serve society with fast (5), employee have a good capabilities in dealing complaints from society (9).

The attributes that are included in quadrant $\mathrm{A}$ are given civil service has been good (1), an employee serving people with fast (5), an employee has the ethics of providing services (9). Attributes which included in quadrant $\mathrm{B}$, is employees give timely service to society (2), employees are always ready to serve the public (7), employees be friendly and courteous (14), attributes employee uniforms worn complete and neat (17), adequate parking areas (19).

Attributes which included in quadrant $\mathrm{C}$, is employees give of accurate information about processing of documents (6), employees are easily contacted (8), employees ensures of data society secure (11), employees have a sooth in responding to community requests as an user the service (13), employees give the same service regardless of social status (15), the condition of environment the office building of a clean (16), comfort of the waiting room provided (18).

Attributes which included in quadrant $\mathrm{C}$, is absence of a mistakes made employee in the process processing of documents (3), if there is community grievance, employee immediately responded (4), employees have a good knowledge about processing of documents (10), employees understand the needs of the public as service users (12), equipment in the room already complete (20).

\section{CONCLUSION}

Based on results of the analysis of data and calculations through the perception and expectation levels which be described in chart Importance Performance Analysis it can be concluded:

- On Quadrant A, the public was dissatisfied with the existing attributes, so that need to be improved performance be better.

- Quadrant B, the society was satisfied with the performance of the Department of Population

- Attributes in this quadrant have low satisfaction levels and considered did not too important for society, so that the Department did not need to prioritize or to give attention to these attributes.
- Quadrant D, respondents considered that there are factors which are not important but they were pleased with the performance of the Department of Population Tomohon

\section{REFERENCES}

[1] Puspitasari Nia Budi, Hery Suliantoro, Laila Kusumawardhani. 2010. "Analisis Kualitas Pelayanan dengan Menggunakan Integrasi Importance Performance Analysis (IPA) dan Model Kano PT. Perusahaan Air Minum Lyonnaise Jaya Jakarta”. J@TI Undip. Vol V. No 3.

[2] Samosir Zurni Zahara. 2005. "Pengaruh Kualitas Pelayanan Terhadap Kepuasan Mahasiswa Menggunakan Perpustakaan USU”. Jurnal Studi Perpustakaan dan Informasi. Vol 1. No 1.

[3] Desy Herawati. 2011. Perencanaan Peningkatan Kualitas Pelayanan Perijinan pada Pemerintah Kota Padang, Artikel Tesis Program Pasca Sarjana, Universitas Andalas. Padang.

[4] Muluk Asmuliardi. 2003. Analisis Kualitas Pelayanan Jasa Perbankan Studi Kasus : PT. Bank Negara Indonesia (Persero) Tbk Cabang Padang. Jurnal Ilmiah Teknik Industri. Edisi 4. Tahun II. Mei 2003. Hal 51-51.

[5] Nasution. 2004. Manajemen Jasa Terpadu. PT. Ghalia Indonesia.

[6] Astuti Herni Justiana. 2007. "Analisis Kepuasan Konsumen (Servqual Model dan Importance Performance Analysis Model)". Media Ekonomi. Vol. 7. No. 1.

[7] Augusty Ferdinand. 2007. Metode Penelitian Manajemen. Edisi 2. Semarang : CV. Indoprint

[8] Ghozali, Imam. 2005. Aplikasi Analisis Multivariat dengan Program SPSS. Badan Penerbit Universitas Diponegoro. Semarang.

[9] Priyanti Dini Ratih. 2011. Analisis Mutu Pelayanan di Bank Syariah. Tesis. Universitas Gunadarma.

[10] Griffin Tonny and Deborah Edwards. 2012. "Importance-Performance Analysis As A Diagnostic Tool For Urban Destination Managers". An International Journal of Tourism and Hospitality Research. Vol. 23. No. 1.

[11] Mostafa M. Mohamad. 2006. "A Comparison of SERVQUAL and I-P Analysis: Measuring and Improving Service Quality in Egyptian Private Universities". Journal of Marketing for Higher Education. Vol. 16 (2). 